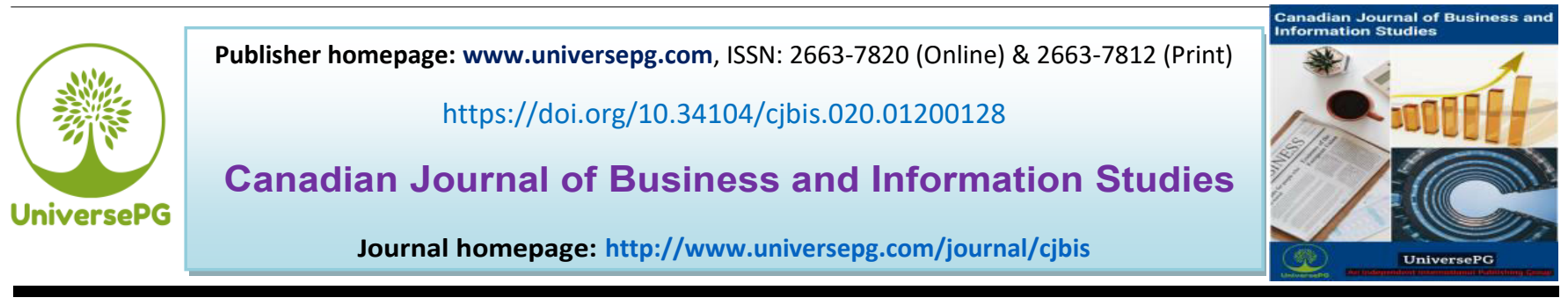

\title{
The Effects of Green Banking Practices on Financial Performance of Listed Banking Companies in Bangladesh
}

\author{
Md. Azmir Hossain ${ }^{1 *}$, Md. Mominur Rahman², Md. Sazzad Hossain², and Md. Razaul Karim \\ ${ }^{1}$ Department of Business Administration, Dhaka International University, Dhaka, Bangladesh; ${ }^{2}$ Department of AIS, Faculty \\ of Business Studies, Comilla University, Cumilla, Bangladesh; and ${ }^{3}$ Dhaka Bank Ltd., Dhaka, Bangladesh. \\ *Correspondence: azmirdu@gmail.com (Md. Azmir Hossain, Associate Professor, Department of Business Administration, \\ Dhaka International University, Dhaka, Bangladesh).
}

\begin{abstract}
This study examines the effects of green banking practices on the financial performance of banks listed in the DSE of Bangladesh covering the period from 2011 to 2020. To move the economy on a sustainable path green banking practices is essential. Green banking practice is a way of contributing environmental and economical performance in the community by providing green finance and initiating green costs in its various sectors, it takes an important part to raise any organization's financial performance through diminishing costs. Green banking is becoming a key issue in the whole world especially in developing countries like Bangladesh. This has been theorized by economists that there is a financial incentive if there is a number of a practice in green banking. In this arena a proactive role can be played by banks besides its operational activities known as the journey of renovation for a greener economy by participating in green finance. The aim of this study is to empirically find the relationship between green banking practices and banks' financial performance by using the panel data set, taking financial variables like return on asset, return on equity, and market value to proxy the banks' performance, and employing green banking practice variables like green cost and volume of the risk management committee. Finally, this study finds that there is a positive relationship between green banking practices and financial performance. The findings generated from this study can be a proper guideline for the bank regulators to take effective decision regarding the environmental issues and thereby make a social contribution, and after all, play a vital role in economic growth. The practitioners, governments, decision makers, academicians, and future researchers can use this study as a policy dialog.
\end{abstract}

Keywords: Green banking, Financial performance, Risk management committee, and Banking companies.

\section{INTRODUCTION:}

Green accounting is popularly regarded as environmental accounting, which includes the expenses and effects of environmental emissions. The overall statistics are thoroughly connected with the company's financial component that has a long-term impact on its economic policy and the environment. The social cost advantages analysis includes many of the corporations'

UniversePG I www.universepg.com projects and activities and assessing the environmental goods and services produced (Jolly, 2014). Environmental accounting has numerous objectives and perspectives that only involve protecting natural assets and changes in well-being caused by environmental impacts (Malik \& Mittal, 2015). "Environmental accounting is a wide field of accounting. This strategy 
offers internal reporting called environmental management accounting; it allows management to determine the price, cost control, and capital budgeting and has the external function is to disclose environmental information favored by public and financial communities. Smart decision-making is being taken on engaging in more environmentally sustainable technology (green industries), and redesigning systems and products will dramatically minimize individual environmental costs. Some do not add value to the design or development (Wan et al., 2015)."

Green banking is related to financial efficiency, as people today are obsessed with profitability and environmental financial performance (Ahmad et al., 2018). "Financial execution may be a subjective degree of how well a firm can utilize resources from its essential mode of business and produce incomes. The term is additionally utilized as a common degree of a firm's general budgetary wellbeing over a given period." Hoque et al., (2019) studied Bangladeshi nonconventional and commercial banks' analysis of monetary success and consumer demand argued that the financial stream was more robust than the others. As a significant part of developing and advancing a nation, Bangladeshi banking services play to grow socio-economic sector significantly (Ibrahim et al., 2014). Fundamentally, The bank sector plays role topromote economic growth in a developing world like Bangladesh (Islam, 2016).

In green accounts, which are the main component of a business or company from which financial output is improved as green costs are improved, the financial performance improvement relies primarily on improving green expenses. In this sense, when the green costs and volume of risk management committees are increased, it results in increased financial efficiency. The green GDP calculations will help rear attentiveness of sustainability issues amongst national governments and politicians, who prefer their countries' rapid financial growth (Rounaghi, 2019).

The dependent variables are return on asset (ROA), stock returns (ROE), and market value (MV). In the case of the financial output of variables, this is used. The independent factors are Green costs and volume of the Risk management committee. We employ the Two- stage least square (2SLS) regression analysis that is a mathematical technique used to analyze structural equations for the research section two-phase less square process to derive the results. The extension of the OLS system is this technique. It is used where the error terms of the dependent variable are added to the separate variables. In the annual report, the numerous pharmaceutical and chemical companies listed in Bangladesh have made recent analyzes on voluntary disclosure of corporate environmental details. Pharmaceutical and pharmaceutical industries are firmly environmentally sustainable and environ-mentally friendly. We typically infer after analyzing some previous reports that some organizations have only qualitative information. Very few environmental monitoring studies have been performed in Bangladesh, the study void, so we have looked into the coded banks' findings concerning Bangladesh's green banking activities (Ullah, 2020; Saha et al., 2020).

In this study, we contribute at least three ways. First, green banking practices are being widely used by the banks in the developed economy, but in developing nations like Bangladesh, there is a need to implement this issue. Thus, this study provides a guideline to the bank regulators to make an effective decision about it. Because of enough study paucity, this study adds attention to generate new dimensions to grow the literature. Second, through this study, green banking practices make a social contribution, ensuring energy savings and paperless documentation in the official activities conducted. This social contribution can meet the need for current requirements and doesn't hamper the generation's future needs. Thirdly, this study has an economic contribution to the nation. This study links a connection between green banking practices and financial performance, suggesting that a profitable organization can subsidize a country's economy.

\section{MATERIALS AND METHODS:}

\subsection{Literature review and hypothesis development-} Laguir et al., (2018) found that high financial efficiency was related to high environmental efficiency. The results also indicate that financial success and environmental performance will reinforce one another, thereby indicating a dynamic two-way relationship. Key role is played by the banks in boosting economic 
development. Banks also have to expand the effect of their operations to help fulfill their stakeholder's needs, including its owners, personnel, regulators, clients, and societies. This influence is reflected in their financial capability, which is at the center of their growth engagement (Beck et al., 2010), namely screening, reporting, and enforceability (Scholtens, 2009). "Over the past few years, banks have significantly exaggerated their obligation to CSR issues (McDonald \& Rundle-Thiele, 2008), especially environmental performance, in their policies, and they have done so for many reasons." "In terms of performance, environmental commitment often lies at the very core of a risk-management strategy (Hsu \& Chen, 2015; Husser \& Evraert-Bardinet, 2014; Sahut \& PasquiniDescomps, 2015)." Banks struggle with concerns relating to green threat control, for example, by using their lending capacity (Benson \& Humphrey, 2008; Boutin-Dufresne \& Savaria, 2004), and these evaluations will monitor the providing or rejection of bank loans building debtors more conscious of environmental performance (Drucker \& Puri, 2009).

The affirmative connotation among green banking and economic performance was agreed with the findings of Laguir et al., (2018). Good green banking participation also increases businesses' credibility and reputation in terms of potentialities (Suchman, 1995). Notably, the intellectuals theorize an optimistic connection between the public's awareness of a company as an environmentally accountable community resident and the company's financial performance incline to appeal image and status as the instructive tools (Lamond et $a l ., 2010)$ as a scholar with a favorable linking impact between an organization's public views as an environmentally-friendly corporate citizen. In their economic landscape, environmental performance may also give banks strategic advantages. For example, banks cannot prove their capacity to handle the costs of comprehensive schemes internationally and therefore, to avoid the charging of harsh regulation utilizing a firm environmental pledge (Sadler \& Lloyd, 2009). "Otherwise, banks can also use their environmental commitment as a differentiation path and thus create new avenues for competitiveness (Porter \& Van der Linde, 1995)." With a slack resource hypothesis, which implies that improved financial results will

UniversePG I www.universepg.com result in the existence of slack (financial and other) resource sources, which offer businesses the potential to engage in and strengthen their environmental performance, such as community affairs and employee associations, or the atmosphere (McGuire et al., 1990). Tsoutsoura, (2004) found strong green banking and financial results and favorable market awareness and credibility for socially accountable businesses by customers. Chih et al., (2010) analyzed the financial company factors, which observed that large-scale and worst return on assets (ROA) banks follow green banking policies. Soana, (2011) discussed the correlation approach between CSR (Corporate Social Responsibility) and CFP (Corporate Financial Performance) in the field of banking. The study showed that internal social policies have a negative connection to ROA, book price, and value to income ratio and indicate that workers' communally conscious management can require higher costs than profits for global banks. Under the major theory of CSR has inadequate gain due to increased costs, social benefit losses, and ultimately decreased benefit and wealth of owners, according to Friedman's basic principle. The ties between CSR and CFP are predicted to be negative for theoreticians. Prior analysis indicates that companies with higher green banking tend to be at less risk and less financial efficiency with the viewpoint of risk control (Ho et al., 2019). Keffas \& Olulu-Briggs, (2011) used the database in Japan to examine the CSR and non-CSR banks' financial results, the United States, and the UK. The study showed that CSR and CFP have a good correlation and shows that for controlling their asset and capital portfolios CSR-based banks have greater asset quality and capital competence and are more competitive

Moreover, Wu \& Shen, (2013) used data in 22 countries with 162 banks. They reveal that the connection between the CSR and financial results is navigated by strategic decisions, altruism, and greenwashing. Results indicate that ROA, ROE, net interest income, and non-interest income for CSR were linked positively to financial performance.

Despite optimistic relations between financial performance and green banking, recent studies Sobhani et al. (2012) and in particular in Europe, Weber, (2005) have reported that few consider environmental con-cerns as 
exploiting financial performance because green banks and financial performance are neutral. "McWilliams \& Siegel, (2000) examined the impact of CSR on CFP from 524 firms taken from KLD data and find that CSR is shown to have a neutral effect on profitability. El Mousaid \& Boutti, (2012) tried to probe CSR divulgations based on the published yearly reports of eight Islamic banks and on the checklist of eight evenly weighted objects with nine dimensions of CSR". The investigation reveals that the financial results (ROA, ROE) and the CSR disclosures index have no statistically relevant relationship. Based on that mixed literature we postulate the hypothesis for this study-

Hypothesis (H1): There is a positive relationship between green banking practices and banks' financial performance.

\subsection{Data, variable and Methodology}

2.2.1. Data - In this study, data are collected from secondary sources. Dhaka stock exchange has 30 banks, as listed up to $14^{\text {th }}$ October 2020 . We select 14 banks, which is $46 \%$ of the whole population. This study covers the period from 2011-2020. The secondary data are collected from the annual reports of the respective banks.

2.2.2. Study Variables - This study uses ROA, ROE, and market value (MV) as the dependent variable.
Return on assets is considered as the ratio of annual values of ROA before loan loss provisions. Return on equity is calculated as the ratio of annual values of return on shareholders' equity. And market value is calculated as the market valuation of the share of each bank.

Further, this study uses green cost (GCOS) and the volume of the risk management committee (VRMC) as the main independent variable. Higher green cost indicates greater green banking practices, and the volume of risk management committee Measures the volume of the risk management committee that manages each bank's green activities. A higher volume of risk management committees indicates better green banking practices.

We consider operating cost ratio and bank size to control the determinants of each bank's financial performance. A control variable is any factor that is controlled or held constant during an experiment; it is important because it can check the result; therefore, it can also verify the behavior of and the association with independent and dependent variables. The operating cost ratio measures the ratio of annual operating expenses to each bank's total assets, and bank size measures the regular logarithm of each bank's total assets. Table 1 represents the detailed depiction of variables

Table 1: Description of variables

\begin{tabular}{|c|c|c|c|}
\hline Variables & Symbol & Definition & Data source \\
\hline \multicolumn{4}{|l|}{ Dependent Variables } \\
\hline \multirow[t]{3}{*}{ Financial Performance } & $\mathrm{ROA}$ & $\begin{array}{l}\text { ROA equals the ratio of annual values of return } \\
\text { on assets before loan loss provisions. }\end{array}$ & $\begin{array}{c}\text { Ahmad et al., 2018; Keffas \& } \\
\text { Olulu-Briggs, 2011; Laguir et al., } \\
2018\end{array}$ \\
\hline & ROE & $\begin{array}{l}\text { ROE equals the ratio of annual values of return } \\
\text { on shareholders' equity. }\end{array}$ & $\begin{array}{c}\text { Keffas \& Olulu-Briggs, 2011; } \\
\text { Lerskullawat \& Prukumpai, } 2017\end{array}$ \\
\hline & MV & $\begin{array}{l}\text { MV equals the market valuation of the share of } \\
\text { each bank. }\end{array}$ & Pusva \& Herlina, 2017 \\
\hline \multicolumn{4}{|c|}{ Green Banking Practice Variables } \\
\hline Green Cost & GCOS & $\begin{array}{l}\text { GCOS equals the total costs in green projects } \\
\text { by each bank. Higher green cost indicates } \\
\text { greater green banking practices. }\end{array}$ & $\begin{array}{c}\text { Ahmad et al., 2018; Keffas \& } \\
\text { Olulu-Briggs, 2011; Laguir } \text { et al., } \\
2018\end{array}$ \\
\hline $\begin{array}{l}\text { Volume of Risk } \\
\text { Management } \\
\text { Committee }\end{array}$ & VRMC & $\begin{array}{l}\text { VRMC is the volume of the risk management } \\
\text { committee that manages the green activities of } \\
\text { each bank. A higher volume of risk }\end{array}$ & Author's idea \\
\hline
\end{tabular}

UniversePG I www.universepg.com 


\begin{tabular}{|c|c|c|c|}
\hline & & $\begin{array}{l}\text { management committee indicates better green } \\
\text { banking practices. }\end{array}$ & \\
\hline \multicolumn{4}{|l|}{ Control Variables } \\
\hline Operating Cost Ratio & OCR. & $\begin{array}{l}\text { Equals the ratio of annual operating expenses } \\
\text { to total assets of each bank }\end{array}$ & Pusva \& Herlina, 2017 \\
\hline Bank size & BSIZE & $\begin{array}{l}\text { Equals natural logarithm of total assets of each } \\
\text { bank }\end{array}$ & Keffas \& Olulu-Briggs, 2011 \\
\hline
\end{tabular}

2.2.3. Research Methodology - This section describes the method used to examine the effects of Green Banking Practices on Financial Performance in the banking industry. A panel regression model was employed, as follows:

$$
X_{i t}=C+G C O S_{i t}+V R M C_{i t}+Y_{i t}+\epsilon_{i t}
$$

In this equation, $X_{i t}$ is the dependent variable of $i$ banks for $\mathrm{t}$ period, which surrogates the three variables, including return on assets (ROA), return on equity (ROE), and market value (MV). Here, GCOS $_{\text {it }}$ is the green cost of $\mathrm{i}$ banks for $\mathrm{t}$ years. $\mathrm{VRMC}_{\mathrm{it}}$ is the volume of the risk management committee of $i$ banks for $t$ years. The GCOS and VRMC are independent variables, $\mathrm{C}$ is the constant term, $\mathrm{Y}_{\mathrm{it}}$ is the control variables of $\mathrm{i}$ banks for $\mathrm{t}$ years, and $\epsilon_{\mathrm{it}}$ is the error terms.

Table 2: Descriptive statistics

\begin{tabular}{|l|r|r|r|r|r|}
\hline & \multicolumn{1}{|c|}{ N } & \multicolumn{1}{c|}{ Minimum } & \multicolumn{1}{c|}{ Maximum } & \multicolumn{1}{c|}{ Mean } & \multicolumn{1}{c|}{ Std. Deviation } \\
\hline ROA & 140 & -0.011 & 1.340 & 0.236 & 0.389 \\
\hline ROE. & 140 & -0.191 & 19.700 & 3.422 & 5.785 \\
\hline MV & 140 & .0418 & 1.0991 & 0.1683 & 0.2579 \\
\hline GCOS & 140 & 1.250 & 139.563 & 107.629 & 253.466 \\
\hline VRMC & 140 & 3 & 14 & 5.34 & 2.239 \\
\hline BSIZE & 140 & 151.067 & 9979.593 & 3151.983 & 2384.241 \\
\hline OCR & 140 & 0.016 & 0.611 & 0.032 & 0.070 \\
\hline Valid N (list-wise) & 140 & & & & \\
\hline
\end{tabular}

Source: Authors' calculation

3.2. Correlation matrix - Table 3 also describes the correlations between the variables and displays that only reasonable collinearity levels prevailing between them. In correlations, multicollinearity refers to

\section{RESULTS AND DISCUSSIONS:}

3.1. Descriptive statistics - Table 2 provides some descriptive statistics of our variables. In this table, the maximum, minimum, mean, and standard deviation values are presented. The Mean of ROA is 0.236 and the standard deviation of ROA is 0.389 , respectively. The mean of ROE is 3.422 and the standard deviation of ROE is 5.785, respectively. The mean of MV is 0.1683 and the standard deviation of MV is 0.2579 , respectively. The mean of green cost (GCOS) is 107.629 and the standard deviation of green cost (GCOS) is 253.466, respectively. The mean of volume of risk management committee (VRMC) is 5.34 and the standard deviation of VRMC is 2.239, respectively. The mean of bank size is (BSIZE) 3151.983 and the standard deviation of BSIZE is 2384.241, respectively. The mean of Operating Cost Ratio (OCR) is 0.032 and the standard deviation of OCR is 0.070 , respectively. exceeding $80 \%$, which causes a problem. The highest value is under $75 \%$ in this correlation, which does not affect the multicollinearity problem. That's why the multicollinearity problem has not arisen. 
Table 3: Correlation matrix

\begin{tabular}{|c|c|c|c|c|c|c|c|}
\hline & ROA & ROE & MV & GCOS & VRMC & BSIZE & OCR \\
\hline $\mathrm{ROA}$ & 1 & & & & & & \\
\hline ROE. & $.748^{* *}$ & 1 & & & & & \\
\hline MV & $.307^{* *}$ & $.246^{*}$ & 1 & & & & \\
\hline GCOS & $.347^{* *}$ & $.373^{* *}$ & $.624^{* *}$ & 1 & & & \\
\hline VRMC & .077 & .197 & $.406^{* *}$ & -.118 & 1 & & \\
\hline BSIZE & .084 & .128 & $.394^{* *}$ & $.595^{* *}$ & -.127 & 1 & \\
\hline OCR & -.044 & -.035 & -.055 & -.027 & -.037 & -.109 & 1 \\
\hline
\end{tabular}

Source: Authors' calculation

3.3. Regression analysis - Table 4 shows the determinants of the financial performance of listed banks. In all models, 1, 2, and 3, the proxies of green accounting practices (GCOS, VRMC) come positive. It recommends that the more the green cost (GCOS), the higher the banks' financial performance (ROA, ROE, $\mathrm{MV})$. The reason behind this financial performance is associated with green accounting practices; this finding is steady with the finding of Laguir et al., (2018). Further, as the models show a positive and significant relationship between VRMC and the financial performance, the greater volume of risk management committee increases banks' financial performance. This variable is generated fromthe author's idea in this study.

In this study, we use two-stage least square modeling to justify our topics. We want to discover the positive relationship between green accounting practices and the bank's financial performance. In model 1, a significant relationship exists between green costs
(GCOS), bank size, and the volume of the risk management committee (VRMC), ROA. On the contrary, operating cost ratio (OCR) poses a negative relationship with ROA in this study.

In model 2, the relationship between green costs (GCOS), volume of the risk management committee (VRMC), and return on equity (ROE) are significant. On the contrary operating cost ratio (OCR) poses a negative relationship with return on equity (ROE) in this study. In model 3 , there is a significant relationship between green costs (GCOS), volume of the risk management committee (VRMC), and market value (MV). On the contrary operating cost ratio (OCR) poses a negative relationship with market value (MV) in this study.

Based on the findings of Table 4 it can be said that the higher the practices of green banking through green cost and volume of the risk management committee, the better the financial performance of banks.

Table 4: Determinants of financial performance

\begin{tabular}{|l|l|l|l|}
\hline \multirow{2}{*}{ Variables } & \multicolumn{1}{c|}{ Model 1 } & \multicolumn{1}{c|}{ Model 2 } & \multicolumn{1}{c|}{ Model 3 } \\
\cline { 2 - 4 } & \multicolumn{1}{c|}{ ROA } & \multicolumn{1}{c|}{ ROE } & \multicolumn{1}{c|}{ MV } \\
\hline GCOS & $0.000^{* * *}$ & $0.000^{* * *}$ & $0.000^{* * *}$ \\
\hline VRMC & 0.009 & $0.430^{*}$ & $0.057^{* * *}$ \\
\hline BSIZE & $0.000^{*}$ & 0.000 & $0.000^{*}$ \\
\hline OCR & -0.306 & $-3.874^{*}$ & -0.039 \\
\hline Constant & $0.320 *$ & $6.008^{* * *}$ & $-228^{* * *}$ \\
\hline F-statistic & 0.030 & 0.010 & 0.000 \\
\hline $\mathrm{R}^{2}$ & $15 \%$ & $18.10 \%$ & $62.30 \%$ \\
\hline
\end{tabular}

Note: Dependent Variables ROA, ROE, and MV in models 1, 3, and 3 respectively. ***, ** and * indicates 1\%, 5\% and $10 \%$ level of significance respectively. 
3.4. Limitations and scope of future study - In this study, we use only two main independent variables as green accounting practices but the others remain unselected. This study is based on a single dimension that is the banking industry. We collect the secondary data from 14 listed banks but the rest of the banks remaining unchosen. Thus the future researcher should use more independent variables as green accounting practices so that a comprehensive study can be conducted. Further, the highly polluted firms can be the study population for future studies. Future researchers can also use the mixed-method study.

\section{CONCLUSION:}

This study inspects the effects of green accounting practices on the financial performance of selected banks from the period of 2011-2020 employing 2 stages least square model. We find a positive relationship that occurs between green accounting practices and the financial performance of banks. This study finds that the greater the green reporting practices the higher the monetary performance of the bank (Rahman and Rahman, 2020). More specifically, the higher the green cost and volume of the risk management committee, the more financial performance of the bank. We test the financial performance through three dimensions. First, the positive and significant association of green cost and risk management committee's volume with ROA implies that the best and improved practices of green banking enhance the ROA of the selected banks. Second, the confident and substantial connotation of green cost and risk management committee's volume with ROE suggests that the superlative and upgraded practices of green banking boosts the ROE of the particular banks. Finally, the MV is positively and significantly influenced by the green cost and volume of risk management committee. When a bank expense more amount on the green accounting practices, then subsequently improves the profitability of banks. Financial performance will be lower if the fewer amounts is expensed on the green accounting practices. This study is essential for the government, investors, shareholders, creditors, and policymakers, etc. They can use this to evaluate the green performance as well as the financial performance of banks. Every organization is legally responsible for the environment where investors and shareholders always want to maximize their profit. To meet both of the required, green accounting practices is the optimal intermediary. Thus, this study makes sense of policy to the stakeholders of society.

\section{ACKNOWLEDGMENT:}

Thanks to all those persons, who have assisted us, providing us co-operation. This paper is under selffunded.

\section{CONFLICTS OF INTEREST:}

Authors declare no conflicts of interest to publish it.

\section{REFERENCES:}

1. Ahmad, M., Waseer, W.A., Hussain, S. \& Ammara, U. (2018). 'Relationship between Environmental Accounting and non-financial Firms Performance: An Empirical Analysis of Selected Firms Listed in Pakistan Stock Exchange, Pakistan', Advances in Social Sciences Research Journal, 5(1), 197-209. https://doi.org/10.14738/assrj.52.4139

2. Beck, T., Demirgüç-Kunt, A. \& Levine, R. (2010). 'Financial institutions and markets across countries and over time: The updated financial development and structure database', The World Bank Economic Review, 24(1), pp. 77-92, https://doi.org/10.1093/wber/lhp016

3. Benson, K.L. \& Humphrey, J.E. (2008). 'Socially responsible investment funds: Investor reaction to current and past returns', $J$. of Banking \& Finance, 32(9), pp. 1850-9. https://doi.org/10.1016/j.jbankfin.2007.12.013

4. Boutin-Dufresne, F. \& Savaria, P. (2004). 'Corporate social responsibility and financial risk', The Journal of investing, 13(1), 57-66. https://doi.org/10.3905/joi.2004.391042

5. Chih, H.-L., Chih, H.-H. \& Chen, T.-Y. (2010). 'On the determinants of corporate social responsibility: International evidence on the financial industry', Journal of Business Ethics, 93(1), pp. 115-35. https://doi.org/10.1007/s10551-009-0186-x

6. Drucker, S. \& Puri, M. (2009). 'On loan sales, loan contracting, and lending relationships', The Review of Financial Studies, 22(7), pp. 2835-72. https://doi.org/10.1093/rfs/hhn067 
7. El Mousaid, F. \& Boutti, R. (2012). 'Relationship between corporate social responsibility and financial performance in Islamic banking', Research journal of finance and accounting, 3(10), pp. 93-103,

https://www.iiste.org/Journals/index.php/RJFA/a rticle/view/3365

8. Ho, A.Y.-F., Liang, H.-Y. \& Tumurbaatar, T. (2019). 'The Impact of Corporate Social Responsibility on Financial Performance: Evidence from Commercial Banks in Mongolia', Advances in Pacific Basin Business, Economics and Finance, Emerald Publishing Limited.

9. Hoque, M.M., Hossain, M.P. \& Bappy, N.M. (2019). 'Financial Performance Analysis of Selected Banks in Bangladesh: a Study on Islamic and Conventional Banks'. JCIRAS, 2(6), 15-30.

https://doi.org/10.13140/RG.2.2.31998.54089/1

10. Hsu, F.J. \& Chen, Y.-C. (2015). 'Is a firm's financial risk associated with corporate social responsibility?', Management Decision, 53(9), pp. 2175-2199.

http://dx.doi.org/10.1108/MD-02-2015-0047

11. Husser, J. \& Evraert-Bardinet, F. (2014). 'The effect of social and environmental disclosure on companies' market value', Management international, 19(1), pp. 61-84.

https://doi.org/10.7202/1028490ar

12. Ibrahim, M., Mohammad, K.D., Hoque, N. \& Khan, M.A. (2014). 'Investigating the performance of Islamic banks in Bangladesh', Asian Social Science, 10(22), p. 165. https://doi.org/10.5539/ass.v10n22p165

13. Islam, K.M.A. (2016). 'Financial Performance Comparison of Top Rated Banking Financial Institutions (BFIs) of Bangladesh', Indian Journal of Science, 23(85), pp. 669-97.

14. Jolly, L. (2014). 'Green accounting-a way to sustainable development', Sai Om Journal of Commerce \& Management. A Peer Reviewed National Journal, 1(5).

https://doi.org/10.1.1.893.8472

15. Keffas, G. \& Olulu-Briggs, O.V. (2011). 'Corporate social responsibility: How does it affect the financial performance of banks?
Empirical evidence from US, UK and Japan', Journal of management and corporate governance, 3, pp. 8-26.

https://www.cenresinjournals.com/wp-content/ uploads/2020/03/page-8-26-260.pdf

16. Laguir, I., Marais, M., El Baz, J. \& Stekelorum, R. (2018). 'Reversing the business rationale for environmental commitment in banking', Management Decision, 56(2), pp. 378-375.

https://doi.org/10.1108/MD-12-2016-0890

17. Lamond, D., Dwyer, R., Arendt, S. \& Brettel, M. (2010). 'Understanding the influence of corporate social responsibility on corporate identity, image, and firm performance', Management Decision, 48(10), pp. 1469-1492. https://doi.org/10.1108/00251741011090289

18. Lerskullawat, P. \& Prukumpai, S. (2017). 'Sustainable development and firm performance: Evidence from Thailand'. https://dx.doi.org/10.2139/ssrn.2902535

19. Malik, P. \& Mittal, A. (2015). 'A study of green accounting practices in India', disclosure, 4(6), 779-787.

https://www.academia.edu/download/60496451/ green_accounting20190905-36657-16gkwoc.pdf

20. McDonald, L.M. \& Rundle-Thiele, S. (2008). 'Corporate social responsibility and bank customer satisfaction', International Journal of Bank Marketing, 26(3), 170-182. https://dx.doi.org/10.1108/02652320810864643

21. McGuire, J.B., Schneeweis, T. \& Branch, B. (1990). 'Perceptions of firm quality: A cause or result of firm performance', Journal of management, 16(1), pp. 167-80.

https://doi.org/10.1177\%2F014920639001600112

22. McWilliams, A. \& Siegel, D. (2000). 'Corporate social responsibility and financial performance: correlation or misspecification?', Strategic management journal, 21(5), 603-9. https://doi.org/10.1002/(SICI)1097-0266(200 005)21:5\%3C603::AID-SMJ101\%3E3.0.CO;2-3

23. Porter, M.E. \& Van der Linde, C. (1995). 'Toward a new conception of the environmentcompetitiveness relationship', Journal of economic perspectives, 9(4), pp. 97-118. https://doi.org/10.1257/jep.9.4.97 
24. Pusva, I.D. \& Herlina, E. (2017). 'Analysis of the implementation of green banking in achieving operational cost efficiency in the banking industry', The Indonesian Accounting Review, 7(2), pp. 203-10.

http://dx.doi.org/10.14414/tiar.v7i2.1602

25. Rahman MM., and Rahman MS. (2020). Green reporting as a tool of environmental sustainability: some observations in the context of Bangladesh, Int. J. Manag. Account. 2(2), 31-37. https://doi.org/10.34104/ijma.020.031037

26. Rounaghi, M.M. (2019). 'Economic analysis of using green accounting and environmental accounting to identify environmental costs and sustainability indicators', International Journal of Ethics and Systems, 35(4), 504-512. http://dx.doi.org/10.1108/IJOES-03-2019-0056

27. Sadler, D. \& Lloyd, S. (2009). 'Neoliberalising corporate social responsibility: A political economy of corporate citizenship', Geoforum, 40(4), pp. 613-22.

https://doi.org/10.1016/j.geoforum.2009.03.008

28. Saha S, Sarker R, and Ahmed SM. (2020). Impact of Green Human Resource Management (GHRM) practices in garment industry: Bangladesh perspective, Int. J. Manag. Account. 2(2), 22-30. https://doi.org/10.34104/ijma.020.022030

29. Sahut, J.-M. \& Pasquini-Descomps, H. (2015). 'ESG impact on market performance of firms: International Evidence', Management International, 19(2), pp. 40-63.

https://doi.org/10.7202/1030386ar

30. Scholtens, B. (2009). 'Corporate social responsibility in the international banking industry', Journal of Business Ethics, 86(2), pp. 159-75. https://doi.org/10.1007/s10551-008-9841-x

31. Soana, M.-G. (2011). 'The relationship between corporate social performance and corporate financial performance in the banking sector', Journal of business ethics, 104(1), p. 133. https://doi.org/10.1007/s10551-011-0894-X

32. Sobhani, F.A., Amran, A. \& Zainuddin, Y. (2012). 'Sustainability disclosure in annual reports and websites: a study of the banking industry in Bangladesh', Journal of Cleaner Production, 23(1), pp. 75-85.

https://doi.org/10.1016/j.jclepro.2011.09.023

33. Suchman, M.C. (1995). 'Managing legitimacy: Strategic and institutional approaches', Academy of management review, 20(3), pp. 571-610.

https://doi.org/10.5465/amr.1995.9508080331

34. Tsoutsoura, M. (2004), 'Corporate social responsibility and financial performance', https://escholarship.org/content/qt111799p2/qt11 1799p2.pdf

35. Ullah MA. (2020). Green banking in the way of sustainable development: an overview of practice and progress in Bangladesh, Can. J. Bus. Inf. Stud., 2(5), 105-119.

https://doi.org/10.34104/cjbis.020.01050119

36. Wan, Y.K., Ng, R.T.L., Ng, D.K.S. \& Tan, R.R. (2015). 'Material flow cost accounting (MFCA)-based approach for prioritisation of waste recovery', J. of Cleaner Production, 107, pp. 602-14.

http://dx.doi.org/10.1016/j.jclepro.2015.05.024

37. Weber, O. (2005). 'Sustainability benchmarking of European banks and financial service organizations', Corporate social responsibility and environmental management, 12(2), pp. 73-87. https://doi.org/10.1002/csr.77

38. Wu, M.-W. \& Shen, C.-H. (2013). 'Corporate social responsibility in the banking industry: Motives and financial performance', Journal of Banking \& Finance, 37(9), pp. 3529-47. https://doi.org/10.1016/j.jbankfin.2013.04.023

Citation: Hossain MA, Rahman MM, Hossain MS, and Karim MR. (2020). The effects of green banking practices on financial performance of listed banking companies in Bangladesh, Can. J. Bus. Inf. Stud., 2(6), 120128. https://doi.org/10.34104/cjbis.020.01200128 (6) 